\title{
REVIEW OF THE NATIONAL RESTOCKING PROGRAMME “ACTIVE PROTECTION OF NATIVE CRAYFISH IN POLAND" 1999-2001
}

\author{
P. ŚMIETANA (1), T. KRZYWOSZ (2), W. STRUŻYŃSKI (3)
}
(1) Department of Ecology, University of Szczecin, ul. Wąska 13, 71-412 Szczecin, Poland E-Mail: leptosp@univ.szczecin.pl
(2) Inland Fisheries Institute, Giżycko, Poland
(3) Department of Zoology, Warsaw Agricultural University, Poland

Reçu le 6 janvier 2004

Received January 6, 2004

Accepté le 3 mai 2004

Accepted May 3, 2004

\begin{abstract}
After the first spread of crayfish plague (aphanomycosis) at the end of the nineteenth century, the formerly abundant populations of native crayfish in Poland declined drastically. Analysis of historical data on the occurrence and distribution of crayfish in Poland led to the conclusion that without human intervention the native crayfish species would be at high risk of being made extinct. The largest programme concerning crayfish monitoring and restocking in Poland was "Active protection of native crayfish in Poland" conducted by the Inland Fisheries Institute, the Department of Ecology, University of Szczecin, the Department of Zoology, Warsaw Agricultural University and the University of Warmia and Mazury that was funded by the EkoFundusz Foundation and Inland Fisheries Institute in 1999-2001. One of the main objectives and results of this programme was the determination of indigenous crayfish distribution in Poland (mainly Astacus astacus and Astacus leptodactylus) and the restocking of suitable habitats with indigenous crayfish.
\end{abstract}

The densest populations ( $>2500$ adult individuals per hectare) were used as a source of restocking material. Restocking was performed in 54 water bodies using a total of 45200 individuals of $A$. astacus and 9800 of $A$. leptodactylus. Between 2001-2002, the success of the restocking programme was monitored. According to the results obtained so far, the restocking exercise has been successful in at least $60.8 \%$ of the cases.

Key words: Astacus astacus, Astacus leptodactylus, distribution, restocking.

\section{REVUE DU PROGRAMME NATIONAL DE RÉINTRODUCTION « PROTECTION ACTIVE DE L'ÉCREVISSE NATIVE EN POLOGNE 1999-2001 »}

\section{RÉSUMÉ}

A la suite du premier épisode de peste de l'écrevisse (aphanomycosis) en Pologne à la fin du XIXe siècle, les populations d'écrevisses autochtones qui étaient alors très abondantes ont vu leur nombre diminuer de façon drastique. L'analyse des données historiques concernant la présence et la distribution des écrevisses en Pologne conduit à la conclusion que sans intervention humaine les espèces d'écrevisses natives auraient eu un grand risque de disparaître. Le programme de "Protection active des écrevisses natives de Pologne » crée par la fondation EkoFundusz en 1999-2001 fut le plus important 
des programmes concernant la gestion des écrevisses et leur réintroduction en Pologne et fut conduit par l'Institut National de la Pêche, les départements d'écologie et de zoologie de I'Université de Szczecin, I'Université Agricole de Varsovie et les Universités de Warmia et de Mazury. Un des objectifs et des résultats principaux fut la détermination de la distribution actuelle des écrevisses autochtones en Pologne (principalement Astacus astacus et Astacus leptodactylus) et le repeuplement des habitats appropriés avec des écrevisses indigènes.

Les populations les plus denses (>2500 adultes par hectare) furent utilisées comme source de matériel biologique pour les actions de repeuplement. 45200 individus de l'espèce $A$. astacus et 9800 de l'espèce $A$. leptodactylus ont servi à la réintroduction de l'écrevisse dans 54 bassins hydrographiques. Entre 2001 et 2002 les zones de réintroductions ont été surveillées. D'après les résultats obtenus jusque là, l'effort de repeuplement a été couronné de succès dans au moins $60,8 \%$ des cas.

Mots-clés : Astacus astacus, Astacus leptodactylus, distribution, réintroduction.

\section{INTRODUCTION}

Indigenous crayfish species were originally quite common and abundant in Poland. It was for example reported in a chronicle from the seventeenth century, that during the Polish-Swedish war, the Polish King fed his army with crayfish (LEŃKOWA, 1962). The first more detailed scientific data, which reflected the abundance of crayfish, were from reports about crayfish export in 1920s and 1930s. The maximum annual noble crayfish export exceeded 600 tons before 1940 (Figure 1).

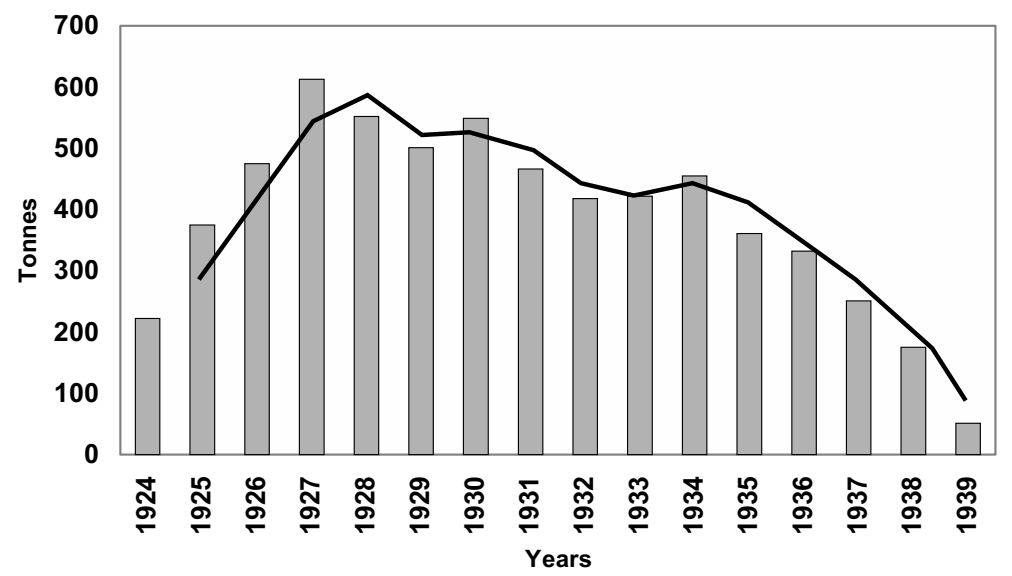

Figure 1

Export of noble crayfish in Poland between 1924 and 1939 (LEŃKOWA, 1962)

\section{Figure 1}

Exportation d'écrevisses nobles en Pologne entre 1924 et 1939 (LEŃKOWA, 1962).

In the 1950 s and 1960s, A. astacus and A. leptodactylus populations were commercially exploited in the whole of Poland. The possibility to export crayfish was the main reason for its quite intensive exploitation. The yield were therefore high during this period, although much more lower than before 1940. The main reason for this decrease in yield was the change of the Polish borders after the Second World War affecting about $60 \%$ of the former catchments areas. 
Figure 2 shows that since the beginning of the 1960s a considerable decrease in commercial catches was observed because of the decrease in abundance of crayfish stocks (GIELO, 1999). Up to now, the total crayfish catch has continuously declined to only 1-2 tons per year (Figure 2), which has been mentioned already by various other authors (GIRSZTOWTT, 1967; KOSSAKOWSKI, 1972; MASTYŃSKI and KACZMAREK, 1976; STRUŻYŃSKI and ŚMIETANA, 1999).

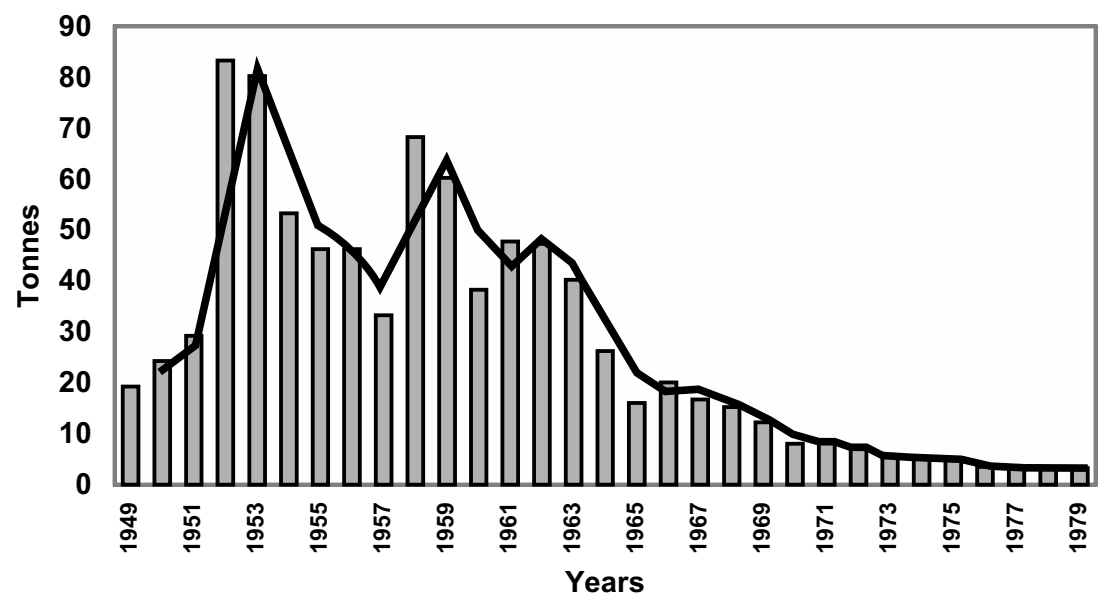

Figure 2

Yield of noble crayfish in Poland during period (1949-1979) (PYKA and KRAŚNIEWSKI, 1997).

\section{Figure 2}

Captures d'écrevisses nobles en Pologne durant la période (1949-1979) (PYKA and KRAŚNIEWSKI, 1997).

The program "Active protection of native crayfish in Poland" was the first integrated joint activity aiming at the improvement of the situation for native crayfish species in this part of Europe. The project was carried out between 1999-2001 by the Institute of Inland Fisheries in Olsztyn, the Department of Ecology of University of Szczecin in Szczecin, the Department of Zoology of Warsaw Agriculture University in Warsaw and the University of Warmia and Mazury in Olsztyn. Financial support for the program realization came form EkoFundusz Foundation, in Warsaw, Poland.

The main task of the program was to describe the current status of native crayfish and to restore stocks of noble and narrow-clawed crayfish in sites where they had disappeared and where the factor responsible for their disappearance was not present any more. "Active protection of native crayfish in Poland" was established as a core programme for any local restocking activity, which is conducted in Poland nowadays. Additionally, the actual environmental situation is improving and thus providing the basis for restocking activities in Poland. The change of land use since 1989 coincided with improvement of surface water quality. Many local point sources of pollution disappeared (dairies, breweries etc.) and changes in the agricultural and forest management reduced most negative effects on the surface water quality and as well as the morphological situation. Moreover, changes in the inland fishery management (i.e. a drastic decrease of intensive eel (Anguilla anguilla L.) breeding, provided much better perspectives for native crayfish in Polish surface waters. 


\section{MATERIAL AND METHODS}

\section{Historic and recent status}

The first step of the program was an analysis of historical data on crayfish distribution followed by gathering field evidence of their current distribution. The monitoring data were also used to estimate the possibility to use some recent populations as a source for restocking material. The second step of the program was to determine the quality of ponds and rivers in terms of finding sites suitable for restocking activities. The action of reintroductions and monitoring of the their effectiveness was the last step of the overall program.

Data on distribution were collected in several ways. First, a field control was undertaken at crayfish sites reported in the literature. The publications used as a main guidance were LEŃKOWA (1962) and the Catalogue Faunae Poloniae (JAŻDŻEWSKI and KONOPACKA, 1995). Additional data came from interviews and questionnaires sent to managers of water reservoirs especially at the Polish Anglers Union (PZW), Nature Parks and Landscape Parks. Because of the potential lack of the informants to differentiate between crayfish species, each reported stock of native crayfish species was checked in accordance with a protocol described by SCHULZ (2000) and verified in the field by the authors.

If an occurrence of native crayfish species was confirmed, a more detailed control of the catchment was conducted using traps. For the estimation of population sizes, markrecapture methods (LAPPALAINEN and PURSIAINEN, 1995) were applied or the catch per unit effort (CPUE) was estimated. The most abundant populations with over 2500 individuals per ha for lakes and 9 CPUE for rivers were used as sources for restocking purposes. Professional fishermen performed the catches of restocking material by trapping during the official season for crayfishing from $15^{\text {th }}$ August up to $15^{\text {th }}$ October. Captured crayfish were checked for porcelain disease and burn spot disease.

\section{Restocking program}

The choice of lakes suitable for restocking was made primarily on the basis of analysis of literature data. We mainly focused on lakes, which were reported as former abundant crayfish sites but where populations were destroyed by intensive eel breeding. As the most appropriate water basins for reintroduction activities, lakes originally used for intensive eel farming were selected. The annual yield of eel in those lakes reached up to $9 \mathrm{~kg}$ per hectare, while the total yield was up to $25 \mathrm{~kg}$ of fish per hectare (unpublished data of State Fish Farm in Miastko). Annual restocking rate was up to 275 eel fries (monteé) per hectare (GIELO, 1999). Eel populations of this density have the potential to destroy noble crayfish populations (KOSSAKOWSKI, 1969). Apart from Pomerania region, the negative effect of eels on crayfish was observed by GIELO (1999) in the Międzyrzecz region (western Poland). Intensive eel production collapsed at the end of the 1980s because of difficulties in obtaining restocking material and a rapid increase of prices. Moreover, eel populations became infected by the Asiatic nematode Anguilicolla crassus (first evidence in 1989, (WŁASOW, 1991)), which can severely affect the growth rate of eels. As eel is considered as the main single reason for crayfish disappearance, it is assumed that after eliminating this factor these lakes would be highly suitable for the reintroduction of crayfish.

Lakes where crayfish plague was reported as factor eliminating crayfish were omitted as place for potential restocking. There was assumed a priori that they could have been still infested by this illness.

However spread of Aphanomyces astaci was evident in Polish waters (ALDERMAN, 1996) only in some cases was scientifically confirmed (KOZŁOWSKI 1969; CZECZUGA 
et. al., 1998). Moreover, to have access to the limited amount of restocking material, restocking activity was focused mostly on waters not reported as place of crayfish plague in history.

The selected lakes were further checked in terms of spiny-cheek crayfish (Orconectes limosus Raf.) occurrence and the general water quality was controlled. Parameters such as Chlorophyll a concentration, transparency, $\mathrm{pH}, \mathrm{O}_{2}, \mathrm{~N}-\mathrm{NH}_{4}, \mathrm{~N}-\mathrm{NO}_{3}, \mathrm{P}-\mathrm{PO}_{4}$, total $\mathrm{P}, \mathrm{COD}$ (Mn), $\mathrm{Ca}$ and $\mathrm{Mg}$ concentrations were measured. Additionally, data on dominant bottom substrates in littoral areas, phytoplankton, and dominant plant species were gathered. On the basis of these data, the levels of eutrophication (lakes) or the saprobic status (rivers) were estimated. Oligotrophic and mesotrophic lakes as well as oligosaprobic and $\alpha$-mesosaprobic rivers were qualified as appropriate for restocking of $A$. astacus. For $A$. leptodactylus eutrophic lakes were chosen. Moreover, the risk of pollution and the possibility of uncontrolled introduction of $\mathrm{O}$. limosus were estimated using data on the level of anthropogenic pressure (angling, bathing, diving etc.) and distance to the closest villages.

A similar procedure was followed for the rivers. The only difference is the reason of destruction of the formerly abundant crayfish populations. Various unpublished information suggest that water pollution caused by dairy, brewery, or pig farming was the most important factor. In cases where it was clear that the sources of river pollution did not exist any more, the river was chosen for further examination. Seventy sites were examined in total.

The restocking procedure was performed during the official crayfish catching season in 1999 and 2000. The total amount of material used for restocking is presented in Table I.

\section{Table I}

Total amount and some features of restocking material used in programme.

\section{Tableau I}

Effectif et quelques caractéristiques du matériel de repeuplement utilisé dans le programme.

\begin{tabular}{cccccc}
\hline Species & $\begin{array}{c}\text { Number of } \\
\text { individuals } \\
\text { (Approx.) }\end{array}$ & $\begin{array}{c}\text { Total } \\
\text { weight } \\
\mathbf{( k g )}\end{array}$ & $\begin{array}{c}\text { Total length } \\
\text { of body } \\
\mathbf{( c m )}\end{array}$ & $\begin{array}{c}\text { Mean } \\
\text { weight } \\
\mathbf{( g )}\end{array}$ & $\begin{array}{c}\text { Sex ratio } \\
\text { Females: } \\
\text { Males }\end{array}$ \\
\hline A. astacus & 45200 & 1583.4 & $7-12$ & 35 & $3: 1$ \\
\hline A. leptodactylus & 9800 & 708.4 & $6-14$ & 72 & $3: 1$ \\
\hline
\end{tabular}

The number of specimens used for reintroduction depended on the lake surface (from about 10 to 50 individuals per hectare) or the length of the river stretch. An additional criterion for the estimation of the number of individuals used to restock was the total number of crayfish caught for restocking. Only local populations were used for restocking to account for genetic differences in populations (SCHULZ and SYPKE, 1999; SCHULZ et al., 2003). Restocking was conducted only once per lake or river.

If the evidence of diseased crayfish in the population was less that $3 \%$, this stock qualified as a source for restocking material. Crayfish from those populations were stored 
in basins with circulating water after sorting out diseased individuals and then transported to the place of reintroduction. The period of holding was never longer than one week.

One year after finishing the restocking, the effectiveness of the restocking was checked. Trapping and night control were used in most cases. In some examples, SCUBA diving was also used. Additionally, searching for exuviae and control of otter excrements were carried out, if possible. In cases where evidence of living crayfish or exuviae was obtained, the site was assumed as successful as a restocking place.

\section{RESULTS AND DISCUSSION}

\section{Historic and recent status}

The primary analysis of literature data connected with field monitoring was made for Pomerania region (north-western Poland). For this region, the most detailed data were available. Moreover, the highest stock density occurred in this area (STRUŻYŃSKI and ŚMIETANA, 1999). Of specific importance was the data reported by SELIGO, 1902, which was compared to information about crayfish distribution from LENKOWA, 1962. In addition, the recent literature data were verified in the field. The results of data comparison for Pomerania region are present in Table II. Table II confirms the rapid rate of native crayfish disappearance. Moreover, the sites reported by SELIGO, 1902, and LENKKOWA, 1962 came from questionnaires and concerned only places of commercial crayfishing, while SMIETANA, unpublished reported all sites confirmed by the field survey. Only one site confirmed in 1999 was abundant enough for commercial catches. In the rest of the lakes, the density of populations was lower than 0.5 CPUE.

The recent field revision of Pomerania lakes, reported by LEŃKOWA, 1962 as native crayfish habitats, showed a total absence of native crayfish species. Only Orconectes limosus was found in $85 \%$ of the lakes formerly inhabited by $A$. leptodactylus and $A$. astacus. A further analysis of the data collected during the recent field survey in comparison to historical data showed a tendency for a habitat change of native crayfish. According to Figure 3 , lakes inhabited by $A$. astacus nowadays are significant smaller (7.5 ha) than in beginning of the twentieth century (75 ha).

\section{Table II}

Freshwater crayfish water bodies in Pomerania region during the 20th century.

\section{Tableau II}

Sites d'écrevisses d'eau douce dans la région de Poméranie au cours du $\mathrm{XX}$ siècle.

\begin{tabular}{l|c|c|c|c}
\hline $\begin{array}{c}\text { Author } \\
\text { Date }\end{array}$ & $\begin{array}{c}\text { Seligo } \\
1902\end{array}$ & $\begin{array}{c}\text { Leńkowa } \\
1962 \\
\text { (State from } \\
\text { 1959) }\end{array}$ & $\begin{array}{c}\text { Śmietana } \\
1990 \\
\text { (unpublished) }\end{array}$ & $\begin{array}{c}1999 \\
\text { (Data collected } \\
\text { during } \\
\text { programe) }\end{array}$ \\
\hline A. astacus & 569 & 86 & 24 & 18 \\
\hline A. leptodactylus & No data & 22 & 6 & 2 \\
\hline $\begin{array}{l}\text { Extinct confirmed } \\
\text { by authors }\end{array}$ & 25 & No data & 1 & 10 \\
\hline
\end{tabular}




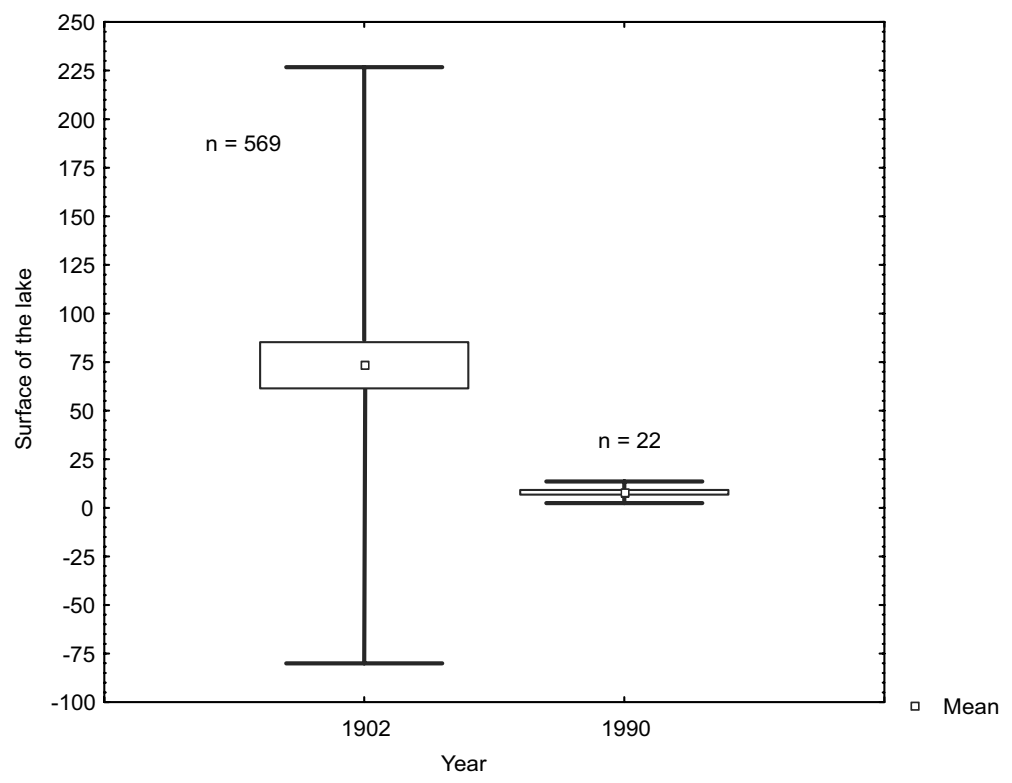

Figure 3

Comparison of the mean surface area of the lakes in the Pomerania region inhabited by Astacus astacus in beginning (SELIGO, 1902) and the end of 20th century (ŚMIETANA, 1999 unpublished).

\section{Figure 3}

Comparaison de la surface moyenne des lacs de la région de Poméranie non peuplés par Astacus astacus au début (SELIGO, 1992) et à la fin du $\mathrm{XX}^{\mathrm{e}}$ siècle (ŚMIETANA, 1999 unpublished).

The results of the research in Pomerania were used as guidance for field surveys conducted in the rest of the Polish territory. A total number of 99 sites of occurrence of $A$. astacus and 28 of $A$. leptodactylus were confirmed for Poland (Figure 4).

\section{Restocking program}

Out of the 70 lakes and rivers examined, 54 were classified as appropriate for restocking. Detailed numbers are presented in Table III. Seven populations of Astacus astacus and three of Astacus leptodactylus were used as a source of restocking material.

In 31 out of the 54 sites used for restocking, the occurrence of crayfish was confirmed already one year after reintroduction (Table III).

Astacus astacus was found in 22 water bodies (14 rivers and 8 lakes), Astacus leptodactylus in 9 lakes. In two rivers and two lakes, the success of restocking was based only on exuviae without evidence of any other indication of living crayfish being present.

During the monitoring of the restocking program, the co-occurrence of native crayfish species with Orconectes limosus was noted. One lake contained Astacus astacus and O. limosus and another one Astacus leptodactylus and Orconectes limosus. Although living individuals of native crayfish species were found in these lakes, the restocking result was considered as unsuccessful. According to additional information both parallel "reintroductions" of $O$. limosus were made by people not aware about the consequences. 


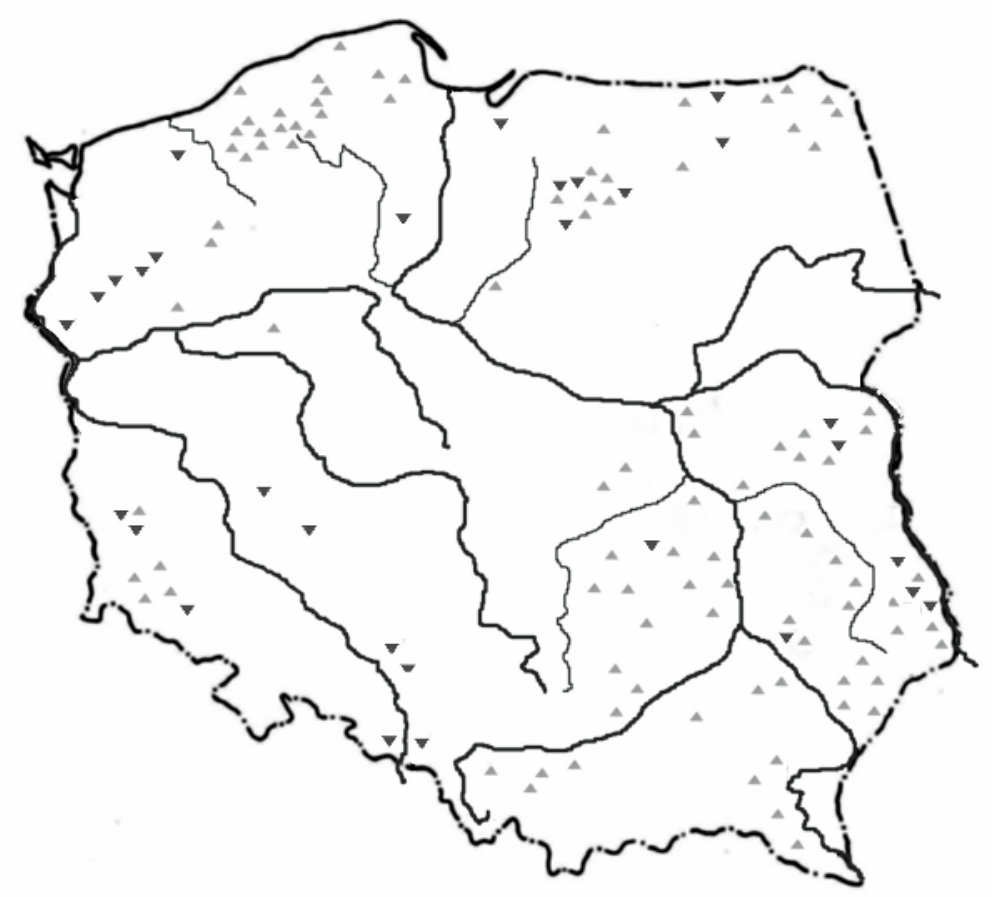

Figure 4

Distribution of native crayfish species in Poland. Sites of occurrence confirmed during realization of restocking programme. Grey triangles: Astacus astacus, Black triangles: Astacus leptodactylus.

Figure 4

Distribution des espèces d'écrevisses natives de Pologne. Sites d'occurrences confirmés pendant la réalisation du programme de repeuplement. Triangles gris : Astacus astacus, triangles noirs : Astacus leptodactylus.

\section{Table III}

Number of water bodies assumed as suitable for restocking with native crayfish species.

Tableau III

Nombre de sites supposés appropriés pour le repeuplement en écrevisses d'espèces natives.

\begin{tabular}{|l|c|c|c|c|c|c|}
\hline & \multicolumn{2}{|c|}{ Total number } & \multicolumn{2}{c|}{ Lakes } & \multicolumn{2}{c|}{ Rivers } \\
\cline { 2 - 7 } & restocked & $\begin{array}{l}\text { confirmed } \\
\text { and } \\
\text { assumed } \\
\text { as } \\
\text { successful }\end{array}$ & restocked & $\begin{array}{l}\text { confirmed } \\
\text { and } \\
\text { assumed } \\
\text { as } \\
\text { successful }\end{array}$ & restocked & $\begin{array}{l}\text { confirmed } \\
\text { assumed } \\
\text { as } \\
\text { successful }\end{array}$ \\
\hline $\begin{array}{l}\text { Astacus } \\
\text { astacus }\end{array}$ & 42 & 22 & 19 & 8 & 23 & 14 \\
\hline $\begin{array}{l}\text { Astacus } \\
\text { leptodactylus }\end{array}$ & 12 & 9 & 12 & 9 & 0 & 0 \\
\hline Sum & 54 & 31 & 21 & 17 & 23 & 14 \\
\hline
\end{tabular}




\section{CONCLUSIONS}

The decrease of native crayfish species is also reflected by the fact that Astacus astacus and Astacus leptodactylus were included in the latest published Red List of Threatened Animals in Poland in the category VU - vulnerable (GŁOWACIŃSKI, 2002). As a main danger for native crayfish populations in Poland nowadays appears the invasion of Orconectes limosus. This species still increases its distribution in Poland (LEŃKOWA, 1962; JAŻDŻEWSKI and KONOPACKA 1998; STRUŻYŃSKI and ŚMIETANA, 1999; JAŻDŻEWSKI and KONOPACKA, 1998, SCHULZ and ŚMIETANA, 2001), in Belarus (ALEKHNOVICH et al., 1999), in the Czech Republic (POLICAR and KOZAK, 2000), and in many other European countries (HOLDICH, 2002).

The very good success of the restocking program seems to indicate that number of individuals used per ha of the lake surface is enough to set up "initial populations". The number used were generally within the limits reported by (SCHULZ et al., 2002). In order to assess the overall success it is of course necessary to keep in mind that there might be further sites with indications of a successful restocking to be detected during future monitoring work.

On the other hand the occurrence of non-indigenous species may jeopardize some of the positive effect of restocking programs. The evidence of Orconectes limosus in two restocking sites indicates to what extent native crayfish species are already in danger. Furthermore, changes in land use, which coincide with changes in the land ownership, may affect native populations (SCHULZ et al., 2002).

A common lack of knowledge about the native crayfish situation, and the lack of elementary skill in recognizing crayfish species, lead to a high risk of transmission and further distribution of $O$. limosus. Although the lakes that were chosen as suitable for the restocking programme had a low anthropogenic pressure and were situated a relative long distance from the next settlement, $O$. limosus was introduced in two cases. We conclude that without broad education and information about non-indigenous crayfish species, the efforts of research and restocking activities are still not as successful as possible. Without a broad education about the crayfish situation, even the good law forbidding to release non-indigenous crayfish (even to the same water body), which was introduced in 2000 in Poland, would be still difficult to implement in practice.

\section{ACKNOWLEDGEMENTS}

The authors would like to thank Ralf SCHULZ for reviewing the manuscript and for valuable comments and to Marie-Cecile TROUILHE for the French where needed.

\section{REFERENCES}

ALEKHNOVICH A., ABLOV S., KULESH V., PAREIKO O.A., 1999. Case studies of alien crayfish in Europe. The American spiny-cheek crayfish, Orconectes limosus (Rafinesque), in the fauna of Belarus. In: Crayfish in Europe as alien species. How to make the best of a bad situation? GHERARDI F., HOLDICH D.M. (Eds.), 237-242, A.A. Balkema, Rotterdam.

ALDERMAN D.J., 1996. Geographical spread of bacterial and fungal diseases of crustaceans. Reviews Science and Technology Office Interntional Epizooloitology, 15(2), 603-632.

CZECZUGA B., MUSZYŃSKA E., GODLEWSKA A., 1998. Aquatic Fungi on Certain Species of Crayfish in Water from Different Water Bodies. Polish Journal of Environmental Studies, Vol. 7, 2, 75-82. 
GIELO M., 1999. Wspomnienie o rakach. Przegląd Rybacki, 21, 13-31. In Polish.

GŁOWACIŃSKI Z. (red.), 2002. Red List of Threatened Animals in Poland. Polish Academy of Sciences, Institute of Nature Conservation. Cracow, 141-143.

GIRSZTOWTT Z., 1967. Spadek pogłowia raków w województwie lubelskim. Gospodarka Rybna, 19, 17. In Polish.

HOLDICH D.M., 2002. Distribution of crayfish in Europe and some adjoining countries. Bull. Fr. Pêche Piscic., 367(4), 611-650.

JAŻDŻEWSKI K., KONOPACKA A., 1995. Katalog Fauny Polski. Catalogus faunae Poloniae. XIII, 1, Pancerzowce, Malacostraca, 53, 3-165.

JAŻDŻEWSKI K., KONOPACKA A., 1998. Immigration history and present distribution of crustaceans in polish waters. Crustacean Issues. 12, 55-64. A.A. Balkema, Amsterdam. ISSN 0168-6356.

KOSSAKOWSKI J., 1966., Raki. PWRiL. Warszawa, 5-292. In Polish.

KOSSAKOWSKI J., 1972. The freshwater crayfish in Poland. A short Review of Economic and Research Activities. Freshwater Crayfish, 1, 18-26.

KOZŁOWSKI F., 1969. Dżuma raków w woj. kieleckim. Medycyna Weterynaryjna, 6, 353355. In Polish.

LAPPALAINEN R., PURSIAINEN M., 1995. The estimation of a noble crayfish (Astacus astacus L.) population size. Freshwater Crayfish, 8, 228-234.

LENKOWA A., 1962. Badania nad przyczynami zaniku, sposobami ochrony i restytucji raka szlachetnego Astacus astacus (L.) w związku z rozprzestrzenianiem się raka amerykańskiego Cambarus affinis Say. Ochrona Przyrody, 28, 1-38.

MASTYŃSKI J., KACZMAREK K., 1976. Stan raków w wodach Wielkopolski. Gospodarka Rybna., 28, 20-21. In Polish.

POLICAR T., KOZAK P., 2000. Vyskyt raku v CR. The occurrence of crayfish in the Czech Republic. Vodnany Bul. VURH JU, 1-2, 18-22.

PYKA J., KRAŚNIEWSKI W., 1997. Raki rodzime na Pojezierzu Brodnickim. Komunikaty Rybackie IRŚ, 1, 9-11. In Polish.

SCHULZ R., 2000. Status of the noble crayfish Astacus astacus (L.) in Germany: monitoring protocol and the use of RAPD markers to assess the genetic structure of populations. Bull. Fr. Pêche Piscic, 356, 123-138.

SCHULZ R., ŚMIETANA P., 2001. Occurrence of native and introduced crayfish in Northeastern Germany and Northwestern Poland. Bull. Fr. Pêche Piscic., 361, 629641.

SCHULZ H.K., ŚMIETANA P., SCHULZ R., 2003. Assessment of DNA variations of the noble crayfish (Astacus astacus) in Germany and Poland using Inter-Simple Sequence Repeats (ISSRs). CRAYNET Meeting - European native crayfish with a special focus on Astacus astacus: linking socioeconomics and conservation (in press).

SCHULZ R., STUCKI T., SOUTY-GROSSET C., 2002. Management: Reintroductions and restocking. Bull. Fr. Pêche Piscic, 367, 917-922.

SCHULZ R. and SYPKE, J., 1999. Freshwater crayfish populations Astacus astacus (L.) in Northeast Brandenburg (Germany): analysis of genetic structure using RAPD-PCR. Freshwater Crayfish, 12, 387-395.

SELIGO A., 1902. Die Fischgewässer der Provinz Westpreussen. Commission Verlag von L.Saunier's Buch und Kunsthandlung in Danzig. 
ŚMIETANA P., 2001. On the distribution of narrow-clawed crayfish (Astacus leptodactylus Esch.) in western Poland. Animal Sciences, Scientific Papers of Agricultural University of Poznań. Vol. 3, 25-35.

STRUŻYNSKI W., ŚMIETANA P., 1999. On the distribution of Crayfish in Poland. Freshwater Crayfish, 12, 825-829.

WŁASOW T., 1991. Azjatycki nicień Anguillicola spp. w pęcherzu pławnym węgorza europejskiego Anguilla anguilla L. Komunikaty Rybackie, 3, 21-22 In Polish. 
